\title{
Effect of Inhibition of Angiotensin-Converting Enzyme and/or Neutral Endopeptidase on Neuropathy in High-Fat-Fed C57B1/6J Mice
}

\author{
Lawrence Coppey, ${ }^{1,2}$ Bao Lu, ${ }^{3}$ Craig Gerard, ${ }^{3}$ and Mark A. Yorek ${ }^{1,2}$ \\ ${ }^{1}$ Department of Veterans Affairs Iowa City Health Care System, Iowa City, IA 52246, USA \\ ${ }^{2}$ Department of Internal Medicine, University of Iowa, Iowa City, IA 52246, USA \\ ${ }^{3}$ Ina Sue Perlmutter Laboratory, Children's Hospital, Department of Pediatrics and Medicine, Harvard Medical School,
} Boston, MA 02115, USA

Correspondence should be addressed to Mark A. Yorek, mark-yorek@uiowa.edu

Received 15 February 2012; Revised 14 August 2012; Accepted 28 August 2012

Academic Editor: Jack A. Yanovski

Copyright ( $\odot 2012$ Lawrence Coppey et al. This is an open access article distributed under the Creative Commons Attribution License, which permits unrestricted use, distribution, and reproduction in any medium, provided the original work is properly cited.

\begin{abstract}
We have demonstrated that treating diet-induced obese (DIO) mice with the vasopeptidase inhibitor ilepatril improved neural function. Vasopeptidase inhibitors block angiotensin-converting enzyme (ACE) and neutral endopeptidase (NEP) activity. We propose that increased activity of ACE and NEP contributes to pathophysiology of DIO. To address this issue C57Bl/6J mice or mice deficient in NEP were fed a high-fat diet and treated with ilepatril, enalapril, ACE inhibitor, or candoxatril, NEP inhibitor, using both prevention and intervention protocols. Endpoints included glucose utilization and neural function determination. In the prevention study glucose tolerance was impaired in DIO C57Bl/6J mice and improved with ilepatril or enalapril. Sensory nerve conduction velocity, thermal nociception, and intraepidermal nerve fiber density were impaired in DIO C57Bl/6J mice and improved with ilepatril or candoxatril. In the intervention study only enalapril improved glucose tolerance. Sensory nerve conduction velocity and intraepidermal nerve fiber density were improved by all three treatments, whereas thermal nociception was improved by ilepatril or candoxatril. In NEP-deficient mice DIO impaired glucose utilization and this was improved with enalapril. Nerve function was not impaired by DIO in NEP-deficient mice. These studies suggest that ACE and NEP play a role in pathophysiology associated with DIO.
\end{abstract}

\section{Introduction}

Previously we reported that deletion of neutral endopeptidase (NEP) provides protection from obesity- and diabetesinduced neural complications [1]. We have also shown that treating obese and streptozotocin-diabetic mice with the vasopeptidase inhibitor ilepatril prevented neural complications including slowing of nerve conduction velocity, thermal hypoalgesia, and decreased intraepidermal nerve fiber density [2]. Vasopeptidase inhibitors are drugs that simultaneously inhibit NEP and angiotensin-converting enzyme (ACE) activity [3]. Recent studies have shown increased expression of angiotensin-II-forming enzymes in adipose tissue and increased activity of the renin-angiotensin system being implicated in the development of insulin resistance and type 2 diabetes [4]. NEP is found in many tissues including vascular and renal tissue and its activity is increased by fatty acids and glucose in human microvascular cells [5-9]. In the peripheral nervous system NEP is located in Schwann cell membranes surrounding dorsal root ganglion cells and nerve fibers $[10,11]$. NEP degrades many vaso- and neuroactive peptides including natriuretic peptides, adrenomedullin, bradykinin, and calcitonin-gene-related peptide $[12,13]$. Therefore, inhibition of ACE and NEP activity would be expected to improve vascular and neural function. In this regard we have demonstrated that treating type 1 and type 2 diabetic rats as well as a genetic rat model of obesity with ilepatril improves vascular and neural dysfunction [14-16]. 
However, little information is available about the effect of vasopeptidase inhibitors in animal models of diet-induced obesity.

In order to further elucidate the effects of vasopeptidase inhibitors in peripheral nerve dysfunction associated with obesity we examined the effect of diet-induced obesity on nerve conduction velocity and thermal response latency in the hindpaw of $\mathrm{C} 57 \mathrm{Bl} / 6 \mathrm{~J}$ mice and mice deficient in NEP treated with ilepatril, enalapril, ACE inhibitor, or candoxatril, NEP inhibitor $[1,2]$.

\section{Materials and Methods}

Unless stated otherwise all chemicals used in these studies were obtained from Sigma Chemical Co. (St. Louis, MO).

2.1. Animals. C57Bl/6JJ wild-type mice were purchased from Jackson Laboratories. Breeding pairs of neutral endopeptidase-deficient $\left(\mathrm{NEP}^{-/-}\right)$mice were provided by Drs. Lu and Gerard and are on the C57Bl/6J background [17]. These mice have been bred and a colony created at the Veterans Affairs Medical Center, Iowa City, IA. The C57Bl/6J and $\mathrm{NEP}^{-/-}$ mice were age-matched for these studies. Deficiency of NEP activity was confirmed in $\mathrm{NEP}^{-/-}$mice by measuring the specific activity of NEP in kidney homogenates using the method described by Ayoub and Melzig [18] with modification. Activity of NEP in kidney from C57Bl/6J and $\mathrm{NEP}^{-/-}$ mice was $0.35 \pm 0.02$ and $0.02 \pm 0.02 \mathrm{mM} 7$-amido-3methylcoumarin $(\mathrm{AMC}) / \mathrm{min} / \mathrm{mg}$ protein, respectively $(P<$ 0.001 versus $\mathrm{C} 57 \mathrm{Bl} / 6 \mathrm{~J}$ by unpaired $t$-test). This test was performed on all mice used in these studies in order to confirm that NEP was functionally "knocked out" in the $\mathrm{NEP}^{-/-}$mice.

Mice were housed in a certified animal care facility and food (Harlan Teklad, no. 7001, Madison, WI) and water were provided ad libitum. Adequate measures were taken to minimize pain or discomfort and all of the experiments were conducted in accordance with international standards on animal welfare and were compliant with all institutional and National Institutes of Health guidelines for use of animals (ACURF protocol 1101009).

The study design consisted of prevention and intervention protocols. For the prevention protocol $\mathrm{C} 57 \mathrm{Bl} / 6 \mathrm{~J}$ and $\mathrm{NEP}^{-/-}$mice at 12 weeks of age were divided into five groups. One group was fed a standard chow diet. A second group was fed a high-fat diet containing $24 \mathrm{gm} \%$ fat, $24 \mathrm{gm} \%$ protein, and 41 gm\% carbohydrate (D12451; Research Diets, New Brunswick, NJ). The primary source of the increased fat content in the diet was soybean oil and lard. The control and high-fat diet contained 0.4 and $0.3 \%$ sodium chloride, respectively. The average fat content of the control diet was 4.25 gm\% (Harlan Teklad, no. 7001, Madison, WI). The third through fifth groups were fed the high-fat diet containing ilepatril (500 mg/kg in the diet), candoxatril (30 mg/kg in the diet), or enalapril (500 mg/kg in the diet). These diets were prepared by Research Diets and we provided the drugs. We have found that these doses provide maximal inhibition of NEP and/or ACE activity in vivo $[2,19]$. The experimental period lasted twelve weeks. For the intervention study the same five groups of $\mathrm{C} 57 \mathrm{Bl} / 6 \mathrm{~J}$ and $\mathrm{NEP}^{-/-}$mice at 12 weeks of age were fed the control diet (group 1) or high-fat diet (groups 2-5) for 12 weeks. Afterwards, the four groups of high-fat-fed mice were fed a high-fat diet with no additions (group 2) or high-fat diet containing ilepatril, candoxatril, or enalapril (groups 3-5) for 12 weeks. The mice on the control diet remained on the control diet.

2.2. Intraperitoneal Glucose Tolerance Test. After an overnight fast mice were injected with a saline solution containing $2 \mathrm{~g} / \mathrm{kg}$ glucose, i.p. Immediately prior to the glucose injection and for 120 minutes afterwards blood samples were taken to measure circulating glucose levels with the use of glucose-dehydrogenase-based reagent strips (Aviva AccuChek, Roche, Mannheim, Germany) [2]. Blood samples $(0.6 \mu \mathrm{L})$ were taken from a tail vein that was lanced once.

2.3. Thermal Nociceptive Response. Thermal nociceptive response in the hindpaw was measured using the Hargreaves method with instrumentation provided by IITC Life Science, Woodland Hills, CA (model 390G) as previously described [2]. The test was performed in a blind manner. Thermal nociceptive responses were measured by placing the mouse in the observation chamber on top of the thermal testing apparatus and allowing it to acclimate to the warmed glass surface $\left(33^{\circ} \mathrm{C}\right)$ and surroundings for a period of $15 \mathrm{~min}$. The mobile heat source was maneuvered so that it was under the heal of the hindpaw and then activated, a process that starts a timer and locally warms the glass surface, when the mouse withdrew its paw, the timer, and the heat source was turned off [2]. Following an initial recording, which was discarded, two measurements were made for each hindpaw, with a rest period of $5 \mathrm{~min}$ between each set of measurements. The mean of the measurements, reported in seconds, was used as a measure of the thermal nociceptive response latency.

2.4. Sensory Nerve Conduction Velocity. Mice were anesthetized with Nembutal ( $75 \mathrm{mg} / \mathrm{kg}$, i.p., Abbott Laboratories, North Chicago, IL) and sensory nerve conduction velocities were determined as previously described [1, 2]. Briefly, sensory nerve conduction velocity was recorded in the digital nerve to the second toe by stimulating with a square-wave pulse of $0.05 \mathrm{~ms}$ duration using the smallest intensity current that resulted in a maximal amplitude response (Grass S44 Stimulator; Grass Medical Instruments, Quincy, MA). The sensory nerve action potential was recorded behind the medial malleolus. The maximal sensory nerve conduction velocity was calculated by measuring the latency to the onset/peak of the initial negative deflection and the distance between stimulating and recording electrodes (measured in millimeters using a Vernier caliper). The sensory nerve conduction velocity was reported in meters per second.

2.5. Intraepidermal Nerve Fiber Density. Immunoreactive intraepidermal nerve fiber profiles were visualized using confocal microscopy as previously described [2]. Biopsies of skin of the right hindpaw were fixed, dehydrated, and embedded in paraffin. Sections $(7 \mu \mathrm{m})$ were collected and immunostained with anti-PGP9.5 antibody (rabbit anti-human no. 
TABle 1: Prevention study in C57Bl/6 and $\mathrm{NEP}^{-/-}$mice. Effect of high fat diet ${ }^{+/-}$ilepatril, candoxatril, or enalapril on change in body weight, blood glucose, and epididymal fat mass.

\begin{tabular}{|c|c|c|c|c|c|}
\hline Determination & Control & High fat & High fat + ilepatril & High fat + candoxatril & High fat + enalapril \\
\hline C57Bl/6 mice & $(12)$ & $(11)$ & $(12)$ & $(12)$ & $(10)$ \\
\hline Start body weight (g) & $27.5 \pm 0.4$ & $26.7 \pm 0.5$ & $27.2 \pm 0.6$ & $26.3 \pm 0.5$ & $27.0 \pm 0.5$ \\
\hline End body weight (g) & $32.2 \pm 0.6$ & $42.9 \pm 1.4^{\mathrm{a}}$ & $29.0 \pm 0.9^{\mathrm{b}, \mathrm{c}}$ & $45.3 \pm 0.7^{\mathrm{a}}$ & $29.3 \pm 0.5^{\mathrm{b}, \mathrm{c}}$ \\
\hline Blood glucose $(\mathrm{mg} / \mathrm{dL})$ & $188 \pm 7$ & $183 \pm 8$ & $152 \pm 8$ & $214 \pm 19$ & $177 \pm 10$ \\
\hline Epididymal fat pad (g) & $0.31 \pm 0.05$ & $0.95 \pm 0.08^{\mathrm{a}}$ & $0.29 \pm 0.05^{\mathrm{b}, \mathrm{c}}$ & $1.13 \pm 0.08^{\mathrm{a}}$ & $0.16 \pm 0.02^{\mathrm{b}, \mathrm{c}}$ \\
\hline $\begin{array}{l}\text { Fat pad/final body } \\
\text { weight }(\%)\end{array}$ & $0.95 \pm 0.14$ & $2.21 \pm 0.18^{\mathrm{a}}$ & $0.98 \pm 0.15^{\mathrm{b}, \mathrm{c}}$ & $2.52 \pm 0.21^{\mathrm{a}}$ & $0.54 \pm 0.07^{\mathrm{b}, \mathrm{c}}$ \\
\hline $\mathrm{NEP}^{-1-}$ mice & $(12)$ & $(16)$ & $(12)$ & (14) & $(14)$ \\
\hline Start body weight (g) & $24.5 \pm 0.6$ & $25.6 \pm 0.4$ & $24.2 \pm 0.6$ & $25.1 \pm 0.9$ & $25.7 \pm 0.5$ \\
\hline End body weight (g) & $29.1 \pm 0.6$ & $42.1 \pm 1.3^{\mathrm{a}}$ & $27.1 \pm 1.1^{\mathrm{b}, \mathrm{c}}$ & $43.8 \pm 2.1^{\mathrm{a}}$ & $27.3 \pm 0.8^{\mathrm{b}, \mathrm{c}}$ \\
\hline Blood glucose $(\mathrm{mg} / \mathrm{dL})$ & $139 \pm 8$ & $153 \pm 8$ & $148 \pm 10$ & $173 \pm 12$ & $163 \pm 6$ \\
\hline Epididymal fat pad (g) & $0.24 \pm 0.03$ & $1.09 \pm 0.06^{\mathrm{a}}$ & $0.19 \pm 0.02^{\mathrm{b}, \mathrm{c}}$ & $0.90 \pm 0.04^{\mathrm{a}}$ & $0.21 \pm 0.06^{\mathrm{b}, \mathrm{c}}$ \\
\hline $\begin{array}{l}\text { Fat pad/final body } \\
\text { weight }(\%)\end{array}$ & $0.80 \pm 0.09$ & $2.62 \pm 0.13^{\mathrm{a}}$ & $0.70 \pm 0.07^{b, c}$ & $2.13 \pm 0.15^{\mathrm{a}}$ & $0.60 \pm 0.05^{b, c}$ \\
\hline
\end{tabular}

Data are presented as the mean \pm SEM. ${ }^{a} P<0.05$ compared to control; ${ }^{b} P<0.05$ compared to high fat; ${ }^{\mathrm{c}} P<0.05$ compared to candoxatril. Parentheses indicate the number of experimental animals in each group.

7863-0504 (this antibody cross-reacts with rat, mouse guinea pig, and other species), AbD Serotic, Morpho Sys US Inc., Raleigh, NC) overnight followed by treatment with secondary antibody Alexa Fluor 546 goat anti-rabbit (Invitrogen, Eugene, OR). Profiles were imaged using a Zeiss 710 confocal microscope with a 40x objective and were counted by two individual investigators that were blinded to the sample identity. All immunoreactive profiles within the epidermis were counted and normalized to epidermal length [20]. Length of the epidermis was determined by drawing a polyline along the contour of the epidermis and recording its length in $\mathrm{mm}$. The number of intraepidermal nerve fiber profiles was reported per mm length.

2.6. Data Analysis. The results are presented as mean \pm SE. Comparisons between the groups for body weight, blood glucose, sensory nerve conduction velocity, thermal nociception, and intraepidermal nerve fiber profiles were conducted using a one-way ANOVA and Bonferroni's test for multiple comparisons (Prism software; GraphPad, San Diego, CA). A $P$ value of less 0.05 was considered significant.

\section{Results}

3.1. Effect of High-Fat Diet and Treatment on Weight and Blood Glucose Levels. Presented in Table 1 are weight and blood glucose changes for $\mathrm{C} 57 / \mathrm{Bl} 6 \mathrm{~J}$ and $\mathrm{NEP}^{-/-}$mice used in the prevention study. At 12 weeks of age the beginning body weights of $\mathrm{C} 57 \mathrm{Bl} / 6 \mathrm{~J}$ and $\mathrm{NEP}^{-/-}$mice were similar. When fed a high-fat diet $\mathrm{C} 57 \mathrm{Bl} / 6 \mathrm{~J}$ and $\mathrm{NEP}^{-/-}$mice both gained a similar amount of weight. Treating the high-fat diet with ilepatril or enalapril but not candoxatril completely prevented the gain in weight. The mass of the epididymal fat pad was significantly increased in high-fat-fed mice and mice fed the high-fat diet treated with candoxatril compared to control mice or mice fed the high-fat diet containing ilepatril or enalapril. When calculating the epididymal fat pad mass as a percent of total body weight epididymal fat pad mass was significantly increased in high-fat-fed C57Bl/6J mice and mice fed a high-fat diet containing candoxatril compared to control. Treating the high-fat diet with ilepatril and to a greater extent enalapril prevented the increase in epididymal fat pad mass when presented as percent of final body weight. Similar results were obtained with $\mathrm{NEP}^{-/-}$ mice. Nonfasting blood glucose levels were not significantly different between $\mathrm{C} 57 \mathrm{Bl} / 6 \mathrm{~J}$ and $\mathrm{NEP}^{-/-}$mice fed the control or high-fat diets and not affected by ilepatril, candoxatril, or enalapril treatment.

In the intervention study all mice fed the high-fat diet for the initial 12 weeks of the experimental design gained a significant amount of weight (Table 2). When transferred to a high-fat diet containing ilepatril or enalapril for an additional 12 weeks $\mathrm{C} 57 \mathrm{Bl} / 6 \mathrm{~J}$ and $\mathrm{NEP}^{-/-}$mice lost weight. Mice remaining on the high diet or high-fat diet containing candoxatril continued to gain weight. The epididymal fat mass decreased after $\mathrm{C} 57 \mathrm{Bl} / 6 \mathrm{~J}$ or $\mathrm{NEP}^{-/-}$mice, fed a diet containing high fat for 12 weeks, were given a high-fat diet containing enalapril. The epididymal fat mass also was decreased after $\mathrm{NEP}^{-/-}$mice but not $\mathrm{C} 57 \mathrm{Bl} / 6 \mathrm{~J}$ mice were fed a high-fat diet treated with ilepatril. Treating high-fat-fed $\mathrm{C} 57 \mathrm{Bl} / 6 \mathrm{~J}$ or $\mathrm{NEP}^{-/-}$mice with candoxatril did not reduce epididymal fat mass. A similar trend was observed when the epididymal fat mass data was presented as percentage of final body weight. Nonfasting blood glucose levels were not changed in $\mathrm{C} 57 \mathrm{Bl} / 6 \mathrm{~J}$ or $\mathrm{NEP}^{-/-}$mice fed control or high-fat diets with or without ilepatril, candoxatril, or enalapril.

3.2. Effect of High-Fat Diet and Treatment on Glucose Tolerance. In the prevention study $\mathrm{C} 57 \mathrm{Bl} / 6 \mathrm{~J}$ (Figure 1) and $\mathrm{NEP}^{-/-}$(Figure 2) mice fed the high-fat diet or high-fat diet containing candoxatril had an impaired glucose clearance curve compared to control mice. In contrast, the glucose 
TABLE 2: Intervention study in $\mathrm{C} 57 \mathrm{Bl} / 6$ and $\mathrm{NEP}^{-/-}$mice. Effect of high fat diet ${ }^{+/-}$ilepatril, candoxatril, or enalapril on change in body weight, blood glucose, and epididymal fat mass.

\begin{tabular}{|c|c|c|c|c|c|}
\hline Determination & Control & High fat & High fat + ilepatril & High fat + candoxatril & High fat + enalapril \\
\hline $\mathrm{C} 57 \mathrm{Bl} / 6$ mice & $(23)$ & $(23)$ & $(12)$ & $(11)$ & $(12)$ \\
\hline Start Body Weight (g) & $27.3 \pm 0.3$ & $26.9 \pm 0.4$ & $26.6 \pm 0.3$ & $27.9 \pm 0.6$ & $27.3 \pm 0.6$ \\
\hline 12 week Weight (g) & $31.8 \pm 0.3$ & $44.9 \pm 0.8^{\mathrm{a}}$ & $46.4 \pm 1.2^{\mathrm{a}}$ & $44.2 \pm 1.4^{\mathrm{a}}$ & $44.2 \pm 1.3^{\mathrm{a}}$ \\
\hline End Body Weight (g) & $36.6 \pm 0.4$ & $49.1 \pm 1.1^{\mathrm{a}, \mathrm{d}}$ & $43.3 \pm 1.8^{\mathrm{a}, \mathrm{b}}$ & $52.2 \pm 1.6^{\mathrm{a}, \mathrm{d}}$ & $33.7 \pm 0.9^{\mathrm{b}, \mathrm{d}}$ \\
\hline Blood glucose $(\mathrm{mg} / \mathrm{dL})$ & $170 \pm 9$ & $168 \pm 11$ & $156 \pm 9$ & $149 \pm 11$ & $192 \pm 10$ \\
\hline Epididymal fat pad (g) & $0.45 \pm 0.04$ & $0.85 \pm 0.05^{\mathrm{a}}$ & $1.06 \pm 0.09^{\mathrm{a}}$ & $0.92 \pm 0.04^{\mathrm{a}}$ & $0.57 \pm 0.06^{\mathrm{b}}$ \\
\hline $\begin{array}{l}\text { Fat pad/Final body } \\
\text { weight }(\%)\end{array}$ & $1.36 \pm 0.10$ & $1.75 \pm 0.11^{\mathrm{a}, \mathrm{c}}$ & $2.43 \pm 0.15^{\mathrm{a}, \mathrm{b}}$ & $1.87 \pm 0.13^{\mathrm{a}}$ & $1.67 \pm 0.14^{\mathrm{c}}$ \\
\hline $\mathrm{NEP}^{-1-}$ mice & (9) & $(10)$ & $(9)$ & $(10)$ & $(10)$ \\
\hline Start Body Weight (g) & $26.4 \pm 0.4$ & $27.6 \pm 1.0$ & $26.1 \pm 1.2$ & $26.2 \pm 1.1$ & $25.8 \pm 0.4$ \\
\hline 12 week Weight (g) & $28.0 \pm 0.5$ & $36.8 \pm 2.1^{\mathrm{a}}$ & $34.7 \pm 1.4^{\mathrm{a}}$ & $36.4 \pm 1.2^{\mathrm{a}}$ & $34.8 \pm 1.5^{\mathrm{a}}$ \\
\hline End Body Weight (g) & $30.4 \pm 0.8$ & $50.7 \pm 1.9^{\mathrm{a}, \mathrm{d}}$ & $29.8 \pm 0.8^{\mathrm{b}}$ & $50.3 \pm 1.2^{\mathrm{a}, \mathrm{d}}$ & $30.5 \pm 1.0^{\mathrm{b}}$ \\
\hline Blood glucose $(\mathrm{mg} / \mathrm{dL})$ & $141 \pm 7$ & $172 \pm 16$ & $173 \pm 8$ & $163 \pm 10$ & $184 \pm 13$ \\
\hline Epididymal fat pad (g) & $0.23 \pm 0.06$ & $0.83 \pm 0.03^{\mathrm{a}}$ & $0.45 \pm 0.05^{\mathrm{b}}$ & $0.86 \pm 0.04^{\mathrm{a}}$ & $0.48 \pm 0.08^{\mathrm{b}}$ \\
\hline $\begin{array}{l}\text { Fat pad/Final body } \\
\text { weight }(\%)\end{array}$ & $0.73 \pm 0.17$ & $1.64 \pm 0.07^{\mathrm{a}}$ & $1.48 \pm 0.15^{\mathrm{a}}$ & $1.71 \pm 0.07^{\mathrm{a}}$ & $1.53 \pm 0.19^{\mathrm{a}}$ \\
\hline
\end{tabular}

Data are presented as the mean \pm SEM. ${ }^{\mathrm{a}} P<0.05$ compared to control; ${ }^{\mathrm{b}} P<0.05$ compared to high fat; ${ }^{\mathrm{c}} P<0.05$ compared to ilepatril; ${ }^{\mathrm{d}} P<0.05$ compared to 12 week animals. Parentheses indicate the number of experimental animals in each group.

clearance curve was near normal in $\mathrm{C} 57 \mathrm{Bl} / 6 \mathrm{~J}$ and $\mathrm{NEP}^{-/-}$ mice fed a high-fat diet containing ilepatril or enalapril. In the intervention study feeding $\mathrm{C} 57 \mathrm{Bl} / 6 \mathrm{~J}$ (Figure 3) or $\mathrm{NEP}^{-/-}$(Figure 4) mice for 24 weeks a high-fat diet caused an impaired glucose clearance curve. Treating high-fat-fed $\mathrm{C} 57 \mathrm{Bl} / 6 \mathrm{~J}$ or $\mathrm{NEP}^{-/-}$mice with enalapril for the last 12 weeks of the 24-week period partially corrected glucose utilization. Treating $\mathrm{NEP}^{-/-}$mice with ilepatril also partially corrected glucose utilization (Figure 4). Treating C57Bl/6J mice with ilepatril did not improve glucose utilization nor did treating C57Bl/6J or $\mathrm{NEP}^{-/-}$with candoxatril.

\subsection{Effect of High-Fat Diet on Sensory Nerve Conduction} Velocity, Thermal Nociception, and Intraepidermal Nerve Fiber Profile Density. Data in Figure 5 (left) demonstrate that sensory nerve conduction velocity was significantly decreased in high-fat-fed C57Bl/6J mice compared to control mice and that this was prevented by treating high-fat-fed mice with Ilepatril or candoxatril using a prevention protocol. Data in Figure 5 (center) demonstrate that thermal nociception was significantly decreased in C57Bl/6J mice after 12 weeks of a high-fat diet compared to control mice as indicated by an increase in paw withdrawal latency. Treatment with ilepatril or candoxatril and to a lesser extent enalapril for the 12-week period prevented thermal hypoalgesia in highfat-fed C57Bl/6J mice. Data in Figure 5 (right) demonstrate that the number of intraepidermal nerve fiber profiles was significantly decreased in high-fat-fed $\mathrm{C} 57 \mathrm{Bl} / 6 \mathrm{~J}$ mice and that treatment of these mice with ilepatril or candoxatril but not enalapril for 12 weeks prevented the significant decrease. Sensory nerve conduction velocity, thermal nociception, and intraepidermal nerve fiber density were not impaired in
$\mathrm{NEP}^{-/-}$mice fed a high-fat diet (Figure 6, left, center, and right, resp.).

We also determined the effect of treating high-fat-fed $\mathrm{C} 57 \mathrm{Bl} / 6 \mathrm{~J}$ and $\mathrm{NEP}^{-/-}$mice using an intervention protocol (Figures 7 and 8, resp.). In this study design high-fat-fed mice were untreated for 12 weeks followed by 12 weeks of a high-fat diet with or without treatment. Feeding C57Bl/6J mice a high-fat diet for 24 weeks caused a significant decrease in sensory nerve conduction velocity (Figure 7, left). Treating these mice for the last 12 weeks of the 24-week period with ilepatril, candoxatril, or enalapril reversed the slowing of sensory nerve conduction velocity. The decrease in thermal nociception in high-fat-fed C57Bl/6J mice was reversed by treating mice with ilepatril or candoxatril but not enalapril (Figure 7, center). Treating high-fat-fed C57Bl/6J mice with ilepatril, candoxatril, or enalapril reversed the decrease in intraepidermal nerve fiber profiles (Figure 7, right). Feeding $\mathrm{NEP}^{-/-}$mice a high-fat diet for 24 weeks with or without treatment had no effect on sensory nerve conduction velocity, thermal nociception, or intraepidermal nerve fiber density (Figure 8, left, center, and right, resp.).

\section{Discussion}

The main findings from these studies were that dietinduced obesity caused significant weight gain and impaired glucose utilization in $\mathrm{C} 57 \mathrm{Bl} / 6 \mathrm{~J}$ and $\mathrm{NEP}^{-/-}$mice that was improved when the mice were treated with ilepatril or enalapril using a prevention protocol. Using the intervention protocol enalapril but not ilepatril treatment was effective improving glucose utilization by $\mathrm{C} 57 \mathrm{Bl} / 6 \mathrm{~J}$ mice. Treating C57Bl/6J or $\mathrm{NEP}^{-/-}$mice with candoxatril did not improve 


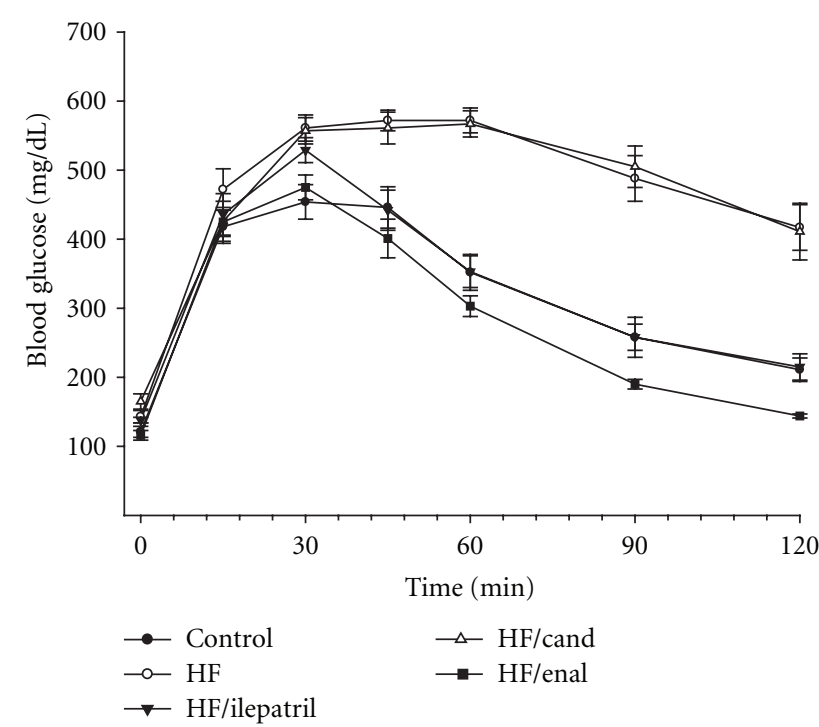

Figure 1: Plasma glucose concentration curve during intraperitoneal glucose tolerance test (IPGTT) for C57Bl/6J mice fed a normal or high-fat-containing diet with or without ilepatril, candoxatril, or enalapril for 12 weeks (prevention protocol). Data are the mean \pm SEM in $\mathrm{mM}$. Fasting basal blood glucose levels were $121 \pm 8,143 \pm 9,138 \pm 4,175 \pm 5$, and $116 \pm 7 \mathrm{mg} / \mathrm{dL}$ for control, high fat, high fat + ilepatril, high fat + candoxatril, and high fat + enalapril, respectively. Control (closed circles), high fat (open circles), high fat + ilepatril (closed innervated triangle), high fat + candoxatril (open triangle), and high fat + enalapril (closed rectangle). The area under the curve (AUC) was significantly different $P<0.01$ for high-fat-fed mice versus control and highfat-fed mice treated with candoxatril versus control. There was no significant difference for AUC between mice fed a high-fat diet containing ilepatril or enalapril versus control. The number of mice in each group was the same as shown in Table 1.

weight gain or glucose utilization. These data suggest that inhibition of ACE and not NEP activity was responsible for improving weight gain and glucose utilization in highfat-fed mice. Diet-induced obesity also caused slowing of sensory nerve conduction velocity, thermal hypoalgesia, and decrease in epidermal nerve fiber density in the paw of the hindlimb in $\mathrm{C} 57 \mathrm{Bl} / 6 \mathrm{~J}$ mice but not $\mathrm{NEP}^{-/-}$mice. The impairment in sensory nerve function endpoints in C57Bl/6J mice fed a high-fat diet was prevented/improved when the mice were treated with ilepatril or candoxatril and to a much lesser extent enalapril using either the prevention or intervention protocol. These data suggest that increased NEP activity/expression but not ACE activity contributes to dietinduced obesity-related deficits in sensory nerve function.

Previous studies have shown that diet-induced obesity in rodent models can be prevented by ACE inhibitors and angiotensin II receptor blockers [21-24]. In addition, dietinduced weight gain and fat mass are reduced, energy expenditure increased, and glucose tolerance improved in mice lacking ACE or the angiotensin II type la receptor $[25,26]$. The mechanisms proposed for the improvement in obesity and glucose tolerance with treatment of rodent models with ACE inhibitors are increased energy

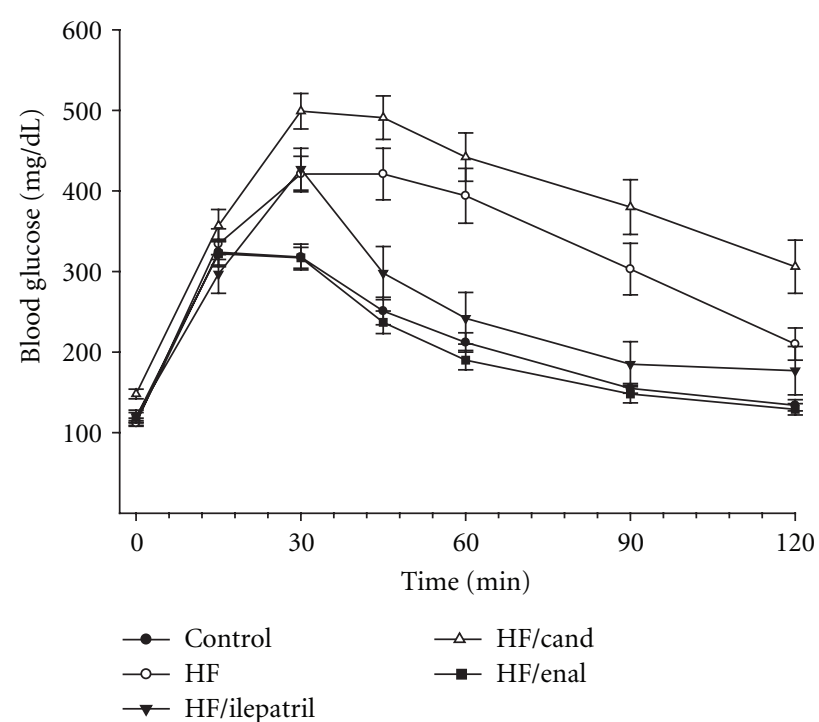

Figure 2: Plasma glucose concentration curve during intraperitoneal glucose tolerance test (IPGTT) for $\mathrm{NEP}^{-/-}$mice fed a normal or high-fat-containing diet with or without ilepatril, candoxatril, or enalapril for 12 weeks (prevention protocol). Data are the mean \pm SEM in $\mathrm{mM}$. Fasting basal blood glucose levels were $113 \pm 5$, $112 \pm 3,120 \pm 8,148 \pm 6$, and $119 \pm 6 \mathrm{mg} / \mathrm{dL}$ for control, high fat, high fat + ilepatril, high fat + candoxatril, and high fat + enalapril, respectively. Control (closed circles), high fat (open circles), high fat + ilepatril (closed innervated triangle), high fat + candoxatril (open triangle), and high fat + enalapril (closed rectangle). The area under the curve (AUC) was significantly different $P<0.01$ and $P<0.05$ for high-fat-fed mice versus control and high-fat-fed mice treated with candoxatril versus control, respectively. There was no significant difference for AUC between mice fed a high-fat diet containing ilepatril or enalapril versus control. The number of mice in each group was the same as shown in Table 1.

expenditure, liver and adipose tissue metabolic modulation, lower concentration of leptin, improved insulin signaling, and increased glucose and fatty acid utilization by muscle [21-30]. In a study comparing the effects of Ramipril, an ACE inhibitor, to ilepatril in JCR:LA-cp rats, an obese, insulin-resistant, hyperinsulinemic, normoglycemic model, it was found that both compounds reduced the surge of plasma insulin in a meal tolerance test by about $50 \%$ but ilepatril was more beneficial in improving vascular reactivity [31]. In our study we found that enalapril trended to be more effective than ilepatril preventing/reducing fat pad mass. This could be because enalapril at the dosage used was a more effective ACE inhibitor than ilepatril in target tissues. In another study using obese Zucker rats it was found that dual inhibition of ACE and NEP improved insulin-mediated glucose disposal more effectively than monotherapy and this effect was linked to increased activation of the kininnitric oxide pathway [32]. In a similar independent study it was found that Omapatrilat, a vasopeptidase inhibitor, induced insulin sensitization and increased myocardial glucose uptake in obese Zucker rats and that the effect of Omapatrilat was greater than Ramipril in part due to stimulation of the $B_{2}$ receptor [33]. Later this group reported that treatment 


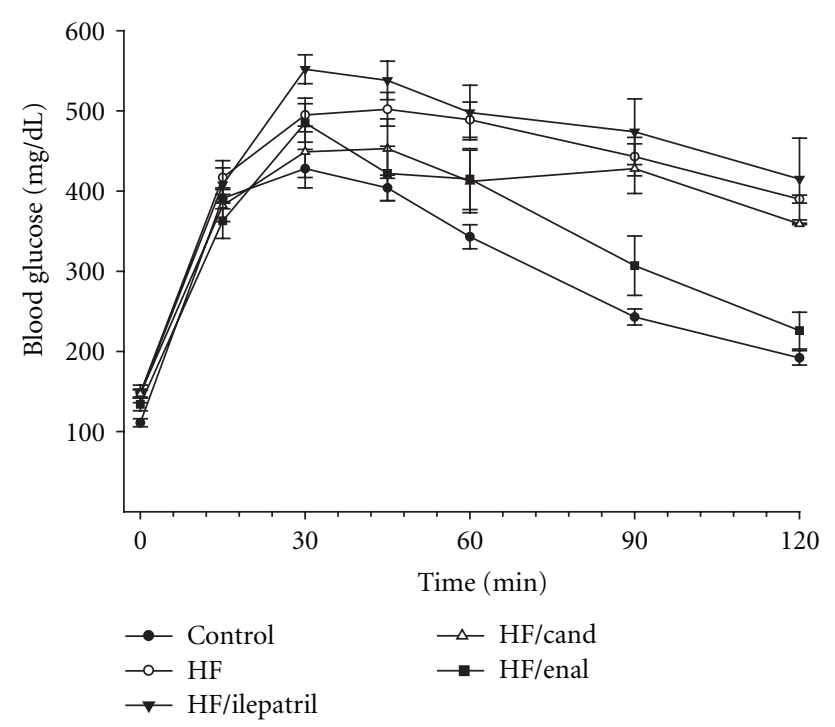

FIgure 3: Plasma glucose concentration curve during intraperitoneal glucose tolerance test (IPGTT) for C57Bl/6J mice fed a normal or high-fat-containing diet for 24 weeks and the high-fat diet with or without ilepatril, candoxatril, or enalapril for the last 12 weeks (intervention protocol). Data are the mean \pm SEM in $\mathrm{mM}$. Fasting basal blood glucose levels were $111 \pm 5,148 \pm 5,177 \pm 11$, $147 \pm 6$, and $134 \pm 8 \mathrm{mg} / \mathrm{dL}$ for control, high fat, high fat + ilepatril, high fat + candoxatril, and high fat + enalapril, respectively. Control (closed circles), high fat (open circles), high fat + ilepatril (closed innervated triangle), high fat + candoxatril (open triangle), and high fat + enalapril (closed rectangle). The area under the curve (AUC) was significantly different $P<0.05$ for high-fat-fed mice versus control and high-fat-fed mice treated with ilepatril versus control. There was no significant difference for AUC between mice fed a high-fat diet containing candoxatril or enalapril versus control. The number of mice in each group was the same as shown in Table 2.

of obese Zucker rats with a vasopeptidase inhibitor increased muscle glucose uptake independent of insulin signaling [34]. In two of these studies protection of bradykinin from degradation by NEP was found to improve insulin action $[32,33]$. Interestingly, it has been shown that natriuretic peptides promote muscle mitochondrial biogenesis and fat oxidation as to prevent obesity and glucose intolerance [35]. The natriuretic peptides are also degraded by NEP [36]. Because NEP is expressed in skeletal muscle in relatively large amounts and being located on the cell surface, NEP is able to hydrolyze peptides in the vicinity of their receptors thereby neutralizing their bioactivity [34, 36]. However, inhibition of ACE may also lead to protection of bradykinin levels by inhibiting kininase-II-mediated degradation of this nonapeptide [37]. Henriksen et al. [38] reported that ACE inhibition by captopril improved glucose transport in insulin-resistant muscle of the obese Zucker rat. They attributed the improvement to modulation of insulin action by bradykinin mediated through $\mathrm{B}_{2}$ receptors and by an increase in nitric oxide production. Since bradykinin and natriuretic peptides may have a role in enhancing insulin

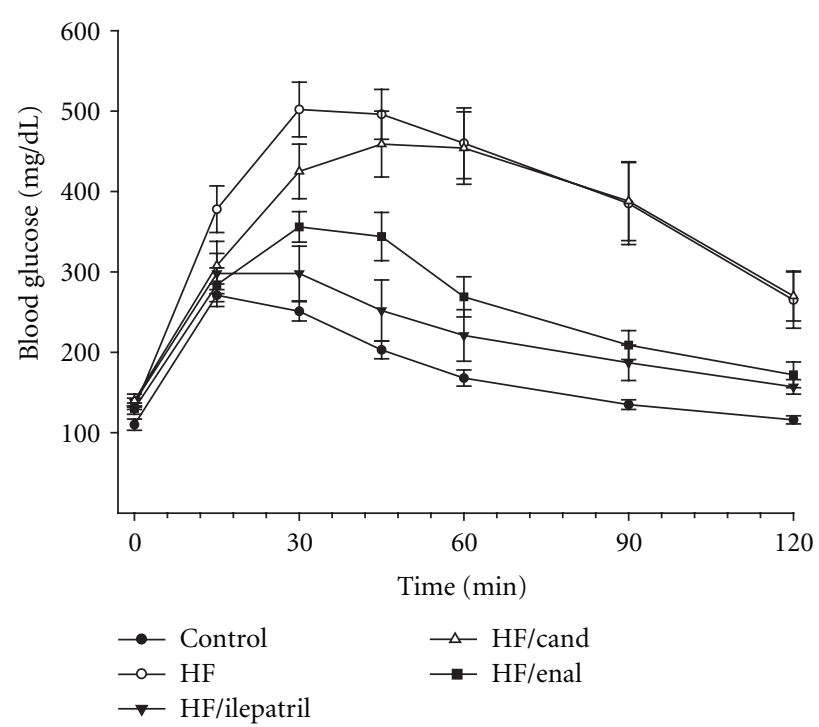

Figure 4: Plasma glucose concentration curve during intraperitoneal glucose tolerance test (IPGTT) for $\mathrm{NEP}^{-/-}$mice fed a normal or high-fat-containing diet for 24 weeks and the high-fat diet with or without ilepatril, candoxatril, or enalapril for the last 12 weeks (intervention protocol). Data are the mean \pm SEM in $\mathrm{mM}$. Fasting basal blood glucose levels were $110 \pm 7,131 \pm 5,138 \pm 5,140 \pm 8$, and $130 \pm 7 \mathrm{mg} / \mathrm{dL}$ for control, high fat, high fat + ilepatril, high fat + candoxatril, and high fat + enalapril, respectively. Control (closed circles), high fat (open circles), high fat + ilepatril (closed innervated triangle), high fat + candoxatril (open triangle), and high fat + enalapril (closed rectangle). The area under the curve (AUC) was significantly different $P<0.01$ for high-fat-fed mice versus control and high fat-fed-mice treated with candoxatril versus control. There was no significant difference for AUC between mice fed a high fat-diet containing ilepatril or enalapril versus control. The number of mice in each group was the same as shown in Table 2.

action and regulating glucose and fatty acid metabolism by muscle protecting their bioactive function by preventing degradation through inhibition of ACE and/or NEP may be a therapeutic approach for treatment of obesity and insulin resistance $[34,36,38]$.

We have previously shown that treating diabetic rats with enalapril improved vascular and nerve endpoints but enalapril was less effective in rats fed a high-fat diet [19, $36,39,40]$. In contrast, we found that treating obese or diabetic rats with ilepatril was more effective than enalapril in improving peripheral nerve dysfunction [19, 36, 40]. This was attributed to be due to improvement in vascular function. We have shown that treating diabetic or dietinduced obese rodents with ilepatril improves vasodilation of blood vessels that provide circulation to the sciatic nerve by reducing oxidative stress and preventing degradation of vasoactive peptides by NEP including calcitonin gene-related peptide and C-type natriuretic peptide thereby maintaining endoneurial blood flow and preventing ischemia [36]. Since NEP degrades both calcitonin gene-related peptide and substance $\mathrm{P}$, peptides important in pain signaling pathways, 


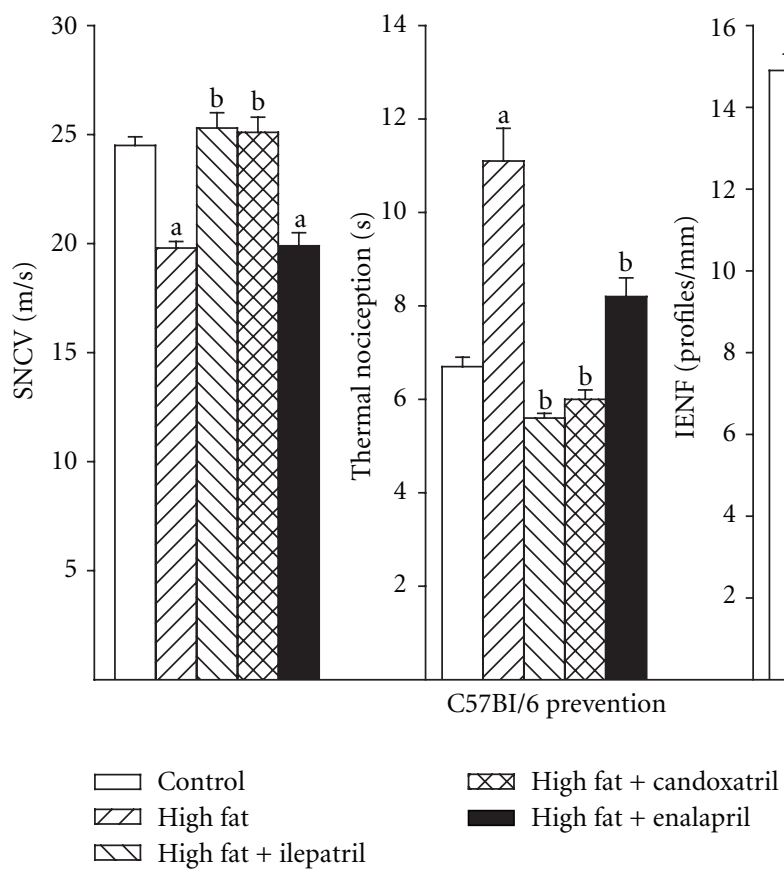

FIGURE 5: Sensory nerve conduction velocity, thermal nociception, and intraepidermal nerve fiber profiles for C57Bl/6J mice fed a normal or high-fat-containing diet with or without ilepatril, candoxatril, or enalapril for 12 weeks (prevention protocol). Control (open bar), high fat (right hatch bar), high fat + ilepatril (left hatch bar), high fat + candoxatril (cross hatch bar), and high fat + enalapril (closed bar). Data are the mean \pm SEM. The number of mice in each group was the same as shown in Table $1 . \mathrm{a}, P<0.05$ versus control; $\mathrm{b}, P<0.05$ versus high-fat-fed mice.

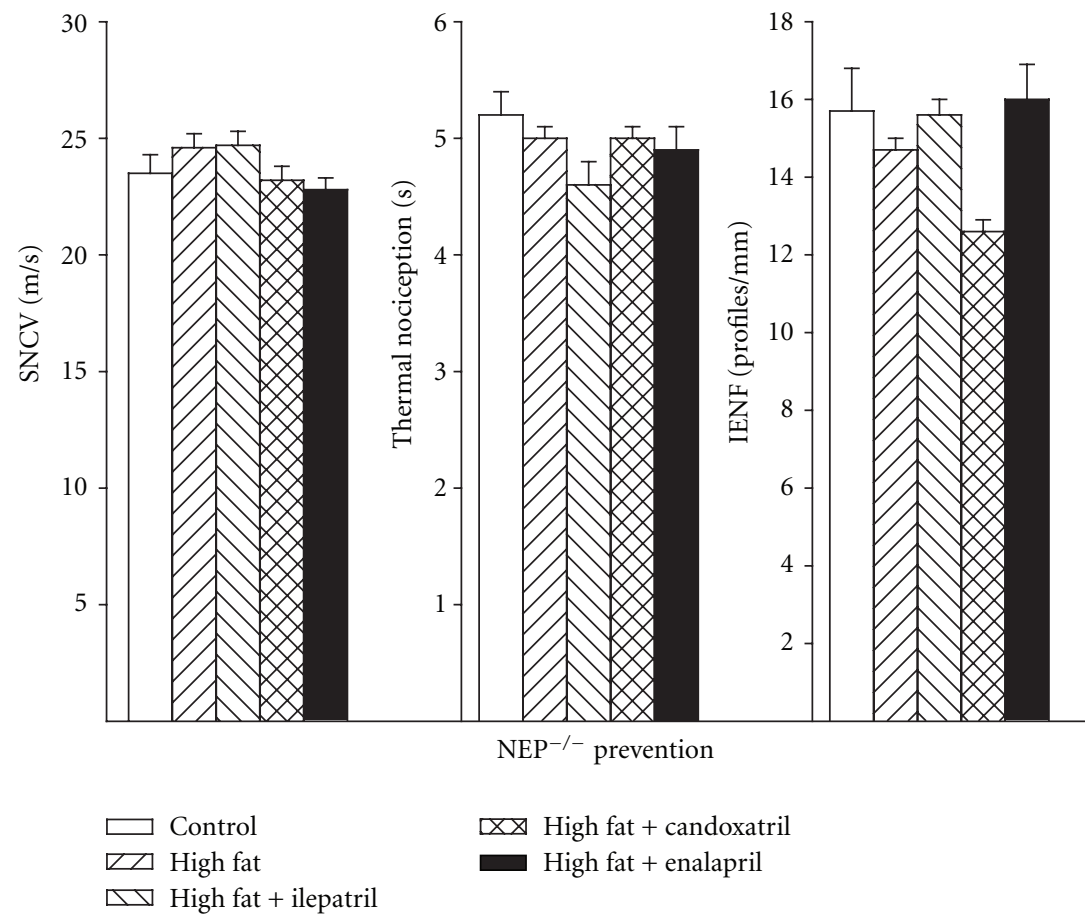

FIGURE 6: Sensory nerve conduction velocity, thermal nociception, and intraepidermal nerve fiber profiles for NEP ${ }^{-/-}$mice fed a normal or high-fat-containing diet with or without ilepatril, candoxatril, or enalapril for 12 weeks (prevention protocol). Control (open bar), high fat (right hatch bar), high fat + ilepatril (left hatch bar), high fat + candoxatril (cross hatch bar), and high fat + enalapril (closed bar). Data are the mean \pm SEM. The number of mice in each group was the same as shown in Table $1 . \mathrm{a}, P<0.05$ versus control; $\mathrm{b}, P<0.05$ versus high-fat-fed mice. 


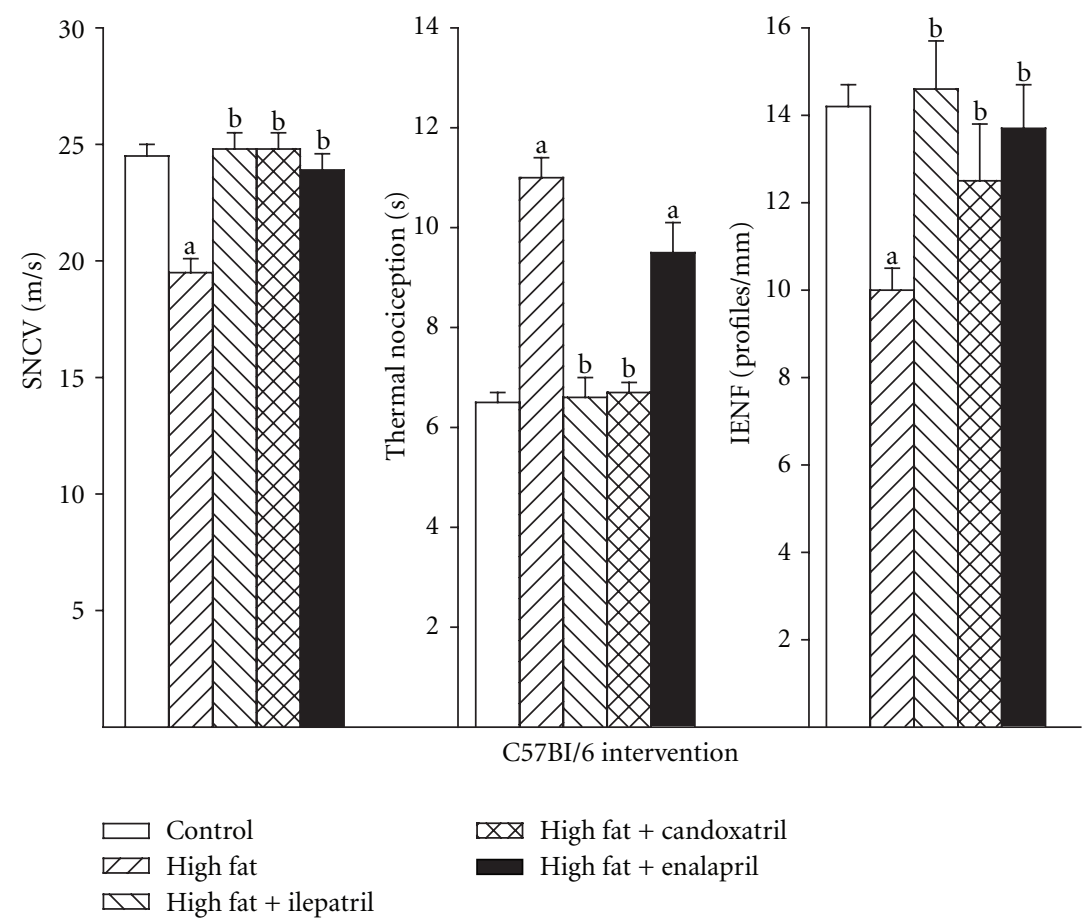

FIGURE 7: Sensory nerve conduction velocity, thermal nociception, and intraepidermal nerve fiber profiles for C57Bl/6J mice fed a normal or high-fat-containing diet for 24 weeks with or without ilepatril, candoxatril, or enalapril for the last 12 weeks (intervention protocol). Control (open bar), high fat (right hatch bar), high fat + ilepatril (left hatch bar), high fat + candoxatril (cross hatch bar), and high fat + enalapril (closed bar). Data are the mean \pm SEM. The number of mice in each group was the same as shown in Table 2 . a, $P<0.05$ versus control; b, $P<0.05$ versus high-fat-fed mice.

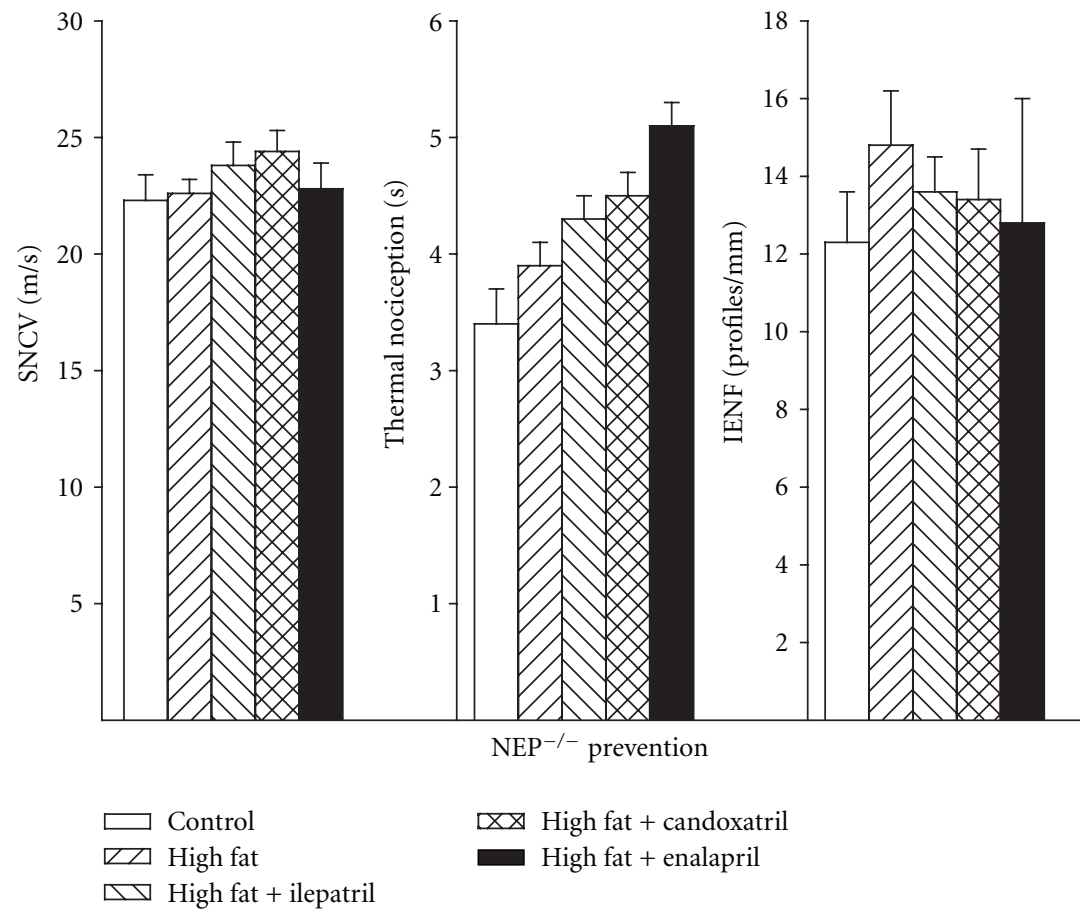

FIGURE 8: Sensory nerve conduction velocity, thermal nociception, and intraepidermal nerve fiber profiles for NEP ${ }^{-/-}$mice fed a normal or high-fat-containing diet for 24 weeks with or without ilepatril, candoxatril, or enalapril for the last 12 weeks (intervention protocol). Control (open bar), high fat (right hatch bar), high fat + ilepatril (left hatch bar), high fat + candoxatril (cross hatch bar), and high fat + enalapril (closed bar). Data are the mean \pm SEM. The number of mice in each group was the same as shown in Table 2 . a, $P<0.05$ versus control; $b$, $P<0.05$ versus high-fat-fed mice. 
it is likely that blocking NEP activity or mice deficient in NEP would maintain higher levels of both of these neuroactive peptides and perhaps be more sensitive to painful stimuli.

\section{Conclusion}

Data from clinical trials clearly suggest that activation of the renin-angiotensin-aldosterone system plays an important role in the pathophysiology of the metabolic syndrome through interaction of a wide range of physiological and molecular mechanisms [41]. More recently in humans activity of NEP has been shown to correlate with body mass index and measures of insulin resistance with increasing activity found in subjects with multiple cardiovascular risk factors [42]. In these studies we found that feeding mice a highfat diet causes weight gain, impaired glucose tolerance, and sensory nerve dysfunction. Inhibition of ACE was effective in reducing weight gain and improving glucose utilization but generally noneffective in improving sensory nerve dysfunction. In contrast, inhibition of NEP improved sensory nerve dysfunction and had no effect in improving weight gain or glucose utilization. Treating high-fat-fed mice with a vasopeptidase inhibitor improved weight gain, glucose utilization, and sensory nerve function. Thus, we conclude that increased activity of NEP is associated with sensory nerve dysfunction in an animal model of diet-induced obesity and that dual inhibition of ACE and NEP may be more effective than monotherapy in reducing insulin resistance and the sensory nerve complications associated with metabolic syndrome.

\section{Acknowledgments}

This material is based upon work supported by a research grant from the Juvenile Diabetes Research Foundation, Department of Veterans Affairs, Veterans Health Administration, Office of Research and Development, Biomedical Laboratory Research and Development (BX001680) and $\mathrm{NIH}$ Award DK073990. The content of this paper is solely the responsibility of the authors and does not necessarily represent the official views of the granting agencies. The authors have no conflict of interestes to report. The authors would like to extend their appreciation to Sanofi Aventis, MERCK, and Pfizer for supplying ilepatril, enalapril, and candoxatril, respectively, for these studies. Sanofi Aventis, MERCK, or Pfizer did not have any involvement in the preparation or decision to submit this paper.

\section{References}

[1] E. P. Davidson, L. J. Coppey, B. Lu et al., "The roles of streptozotocin neurotoxicity and neutral endopeptidase in murine experimental diabetic neuropathy," Experimental Diabetes Research, vol. 2009, Article ID 431980, 2009.

[2] L. J. Coppey, E. P. Davidson, B. Lu, C. Gerard, and M. A. Yorek, "Vasopeptidase inhibitor ilepatril (AVE7688) prevents obesity- and diabetes-induced neuropathy in C57Bl/6J mice," Neuropharmacology, vol. 60, no. 2-3, pp. 259-266, 2011.
[3] M. Weber, "Emerging treatments for hypertension: potential role for vasopeptidase inhibition," American Journal of Hypertension, vol. 12, no. 11, part 2, pp. 139S-147S, 1999.

[4] A. M. Sharma, "Is there a rationale for angiotensin blockade in the management of obesity hypertension?" Hypertension, vol. 44, no. 1, pp. 12-19, 2004.

[5] H. Vatter, L. Schilling, P. Schmiedek, and H. Ehrenreich, "Evidence for functional endothelin-converting enzyme activity in isolated rat basilar artery: effect of inhibitors," Journal of Cardiovascular Pharmacology, vol. 31, no. 1, pp. S64-S67, 1998.

[6] W. Gonzalez, J. M. Soleilhac, M. C. Fournié-Zaluski, B. P. Roques, and J. B. Michel, "Characterization of neutral endopeptidase in vascular cells, modulation of vasoactive peptide levels," European Journal of Pharmacology, vol. 345, no. 3, pp. 323-331, 1998.

[7] R. M. Edwards, M. Pullen, and P. Nambi, "Distribution of neutral endopeptidase activity along the rat and rabbit nephron," Pharmacology, vol. 59, no. 1, pp. 45-50, 1999.

[8] F. Ebihara, G. Seno Di Marco, M. A. Juliano, and D. E. Casarini, "Neutral endopeptidase expression in mesangial cells," Journal of the Renin-Angiotensin-Aldosterone System, vol. 4, no. 4, pp. 228-233, 2003.

[9] P. Muangman, M. L. Spenny, R. N. Tamura, and N. S. Gibran, "Fatty acids and glucose increase neutral endopeptidase activity in human microvascular endothelial cells," Shock, vol. 19, no. 6, pp. 508-512, 2003.

[10] R. Matsas, A. J. Kenny, and A. J. Turner, "An immunohistochemical study of endopeptidase-24.11 ("enkephalinase") in the pig nervous system," Neuroscience, vol. 18, no. 4, pp. 991$1012,1986$.

[11] C. Kioussi, A. Mamalaki, K. Jessen, R. Mirsky, L. B. Hersh, and R. Matsas, "Expression of endopeptidase-24.11 (common acute lymphoblastic leukaemia antigen CD10) in the sciatic nerve of the adult rat after lesion and during regeneration," European Journal of Neuroscience, vol. 7, no. 5, pp. 951-961, 1995.

[12] Q. Pu and E. L. Schiffrin, "Effect of ACE/NEP inhibition on cardiac and vascular collagen in stroke-prone spontaneously hypertensive rats," American Journal of Hypertension, vol. 14, no. 10, pp. 1067-1072, 2001.

[13] J. S. Floras, "Vasopeptidase inhibition: a novel approach to cardiovascular therapy," Canadian Journal of Cardiology, vol. 18, no. 2, pp. 177-182, 2002.

[14] E. P. Davidson, T. L. Kleinschmidt, C. L. Oltman, D. D. Lund, and M. A. Yorek, "Treatment of streptozotocin-induced diabetic rats with AVE7688, a vasopeptidase inhibitor: effect on vascular and neural disease," Diabetes, vol. 56, no. 2, pp. 355362, 2007.

[15] C. L. Oltman, E. P. Davidson, L. J. Coppey, T. L. Kleinschmidt, and M. A. Yorek, "Treatment of Zucker diabetic fatty rats with AVE7688 improves vascular and neural dysfunction," Diabetes, Obesity and Metabolism, vol. 11, no. 3, pp. 223-233, 2009.

[16] E. P. Davidson, L. J. Coppey, T. L. Kleinschmidt, C. L. Oltman, and M. A. Yorek, "Vascular and neural dysfunctions in obese Zucker rats: effect of AVE7688," Experimental Diabetes Research, vol. 2009, Article ID 912327, 2009.

[17] B. Lu, N. P. Gerard, L. F. Kolakowski Jr. et al., "Neutral endopeptidase modulation of septic shock," Journal of Experimental Medicine, vol. 181, no. 6, pp. 2271-2275, 1995.

[18] S. Ayoub and M. F. Melzig, "Induction of neutral endopeptidase (NEP) activity of SK-N-SH cells by natural compounds from green tea," Journal of Pharmacy and Pharmacology, vol. 58, no. 4, pp. 495-501, 2006. 
[19] E. P. Davidson, L. J. Coppey, B. Dake, and M. A. Yorek, "Effect of treatment of sprague dawley rats with AVE7688, enalapril or candoxatril on diet induced obesity," Journal of Obesity, vol. 2011, Article ID 686952, 2011.

[20] K. K. Beiswenger, N. A. Calcutt, and A. P. Mizisin, "Epidermal nerve fiber quantification in the assessment of diabetic neuropathy," Acta Histochemistry, vol. 110, no. 5, pp. 351-362, 2008.

[21] E. L. Santos, K. de Picoli Souza, P. B. Guimarães et al., "Effect of angiotensin converting enzyme inhibitor enalapril on body weight and composition in young rats," International Immunopharmacology, vol. 8, no. 2, pp. 247-253, 2008.

[22] R. S. Weisinger, T. K. Stanley, D. P. Begg, H. S. Weisinger, K. J. Spark, and M. Jois, "Angiotensin converting enzyme inhibition lowers body weight and improves glucose tolerance in C57BL/6J mice maintained on a high fat diet," Physiology and Behavior, vol. 98, no. 1-2, pp. 192-197, 2009.

[23] E. L. Santos, K. de Picoli Souza, E. D. da Silva et al., "Long term treatment with ACE inhibitor enalapril decreases body weight gain and increases life span in rats," Biochemical Pharmacology, vol. 78, no. 8, pp. 951-958, 2009.

[24] K. Araki, T. Masaki, I. Katsuragi, K. Tanaka, T. Kakuma, and H. Yoshimatsu, "Telmisartan prevents obesity and increases the expression of uncoupling protein 1 in diet-induced obese mice," Hypertension, vol. 48, no. 1, pp. 51-57, 2006.

[25] A. P. Jayasooriya, M. L. Mathai, L. L. Walker et al., "Mice lacking angiotensin-converting enzyme have increased energy expenditure, with reduced fat mass and improved glucose clearance," Proceedings of the National Academy of Sciences of the United States of America, vol. 105, no. 18, pp. 6531-6536, 2008.

[26] R. Kouyama, T. Suganami, J. Nishida et al., "Attenuation of diet-induced weight gain and adiposity through increased energy expenditure in mice lacking angiotensin II type 1a receptor," Endocrinology, vol. 146, no. 8, pp. 3481-3489, 2005.

[27] M. Nawano, M. Anai, M. Funaki et al., "Imidapril, an angiotensin-converting enzyme inhibitor, improves insulin sensitivity by enhancing signal transduction via insulin receptor substrate proteins and improving vascular resistance in the Zucker fatty rat," Metabolism, vol. 48, no. 10, pp. 1248-1255, 1999.

[28] E. J. Henriksen, S. Jacob, H. J. Augustin, and G. J. Dietze, “Glucose transport activity in insulin-resistant rat muscle: effects of angiotensin-converting enzyme inhibitors and bradykinin antagonism," Diabetes, vol. 45, supplement 1, pp. S125-S128, 1996.

[29] E. J. Henriksen and S. Jacob, "Effects of captopril on glucose transport activity in skeletal muscle of obese Zucker rats," Metabolism, vol. 44, no. 2, pp. 267-272, 1995.

[30] K. Sugimoto, L. Kazdová, N. R. Qi et al., “Telmisartan increases fatty acid oxidation in skeletal muscle through a peroxisome proliferator-activated receptor- $\gamma$ dependent pathway," Journal of Hypertension, vol. 26, no. 6, pp. 1209-1215, 2008.

[31] J. C. Russell, S. E. Kelly, and S. Schäfer, "Vasopeptidase inhibition improves insulin sensitivity and endothelial function in the JCR:LA-cp rat," Journal of Cardiovascular Pharmacology, vol. 44, no. 2, pp. 258-265, 2004.

[32] V. Arbin, N. Claperon, M. C. Fournié-Zaluski, B. P. Roques, and J. Peyroux, "Acute effect of the dual angiotensinconverting enzyme and neutral endopeptidase 24-11 inhibitor mixanpril on insulin sensitivity in obese Zucker rat," British Journal of Pharmacology, vol. 133, no. 4, pp. 495-502, 2001.
[33] C. H. Wang, N. Leung, N. Lapointe et al., "Vasopeptidase inhibitor omapatrilat induces profound insulin sensitization and increases myocardial glucose uptake in Zucker fatty rats: studies comparing a vasopeptidase inhibitor, angiotensinconverting enzyme inhibitor, and angiotensin II type I receptor blocker," Circulation, vol. 107, no. 14, pp. 1923-1929, 2003.

[34] V. Wong, L. Szeto, K. Uffelman, I. G. Fantus, and G. F. Lewis, "Enhancement of muscle glucose uptake by the vasopeptidase inhibitor, omapatrilat, is independent of insulin signaling and the AMP kinase pathway," Journal of Endocrinology, vol. 190, no. 2, pp. 441-450, 2006.

[35] K. Miyashita, H. Itoh, H. Tsujimoto et al., "Natriuretic peptides/cGMP/cGMP-dependent protein kinase cascades promote muscle mitochondrial biogenesis and prevent obesity," Diabetes, vol. 58, no. 12, pp. 2880-2892, 2009.

[36] M. A. Yorek, “The potential role of angiotensin converting enzyme and vasopeptidase inhibitors in the treatment of diabetic neuropathy," Current Drug Targets, vol. 9, no. 1, pp. 7784, 2008.

[37] H. Y. T. Yang, E. G. Erdös, and Y. Levin, "A dipeptidyl carboxypeptidase that converts angiotensin I and inactivates bradykinin," Biochimica et Biophysica Acta, vol. 214, no. 2, pp. 374-376, 1970.

[38] E. J. Henriksen, S. Jacob, T. R. Kinnick, E. B. Youngblood, M. B. Schmit, and G. J. Dietze, "ACE inhibition and glucose transport in insulin-resistant muscle: roles of bradykinin and nitric oxide," American Journal of Physiology, vol. 277, no. 1, pp. R332-R336, 1999.

[39] L. J. Coppey, E. P. Davidson, T. W. Rinehart et al., "ACE inhibitor or angiotensin II receptor antagonist attenuates diabetic neuropathy in streptozotocin-induced diabetic rats," Diabetes, vol. 55, no. 2, pp. 341-348, 2006.

[40] C. L. Oltman, E. P. Davidson, L. J. Coppey, T. L. Kleinschmidt, B. Dake, and M. A. Yorek, "Role of the effect of inhibition of neutral endopeptidase on vascular and neural complications in streptozotocin-induced diabetic rats," European Journal of Pharmacology, vol. 650, no. 2-3, pp. 556-562, 2011.

[41] S. Engeli, "Role of the renin-angiotensin-aldosterone system in the metabolic syndrome," Contributions to Nephrology, vol. 151, pp. 122-134, 2006.

[42] K. F. Standeven, K. Hess, A. M. Carter et al., "Neprilysin, obesity and the metabolic syndrome," International Journal of Obesity, vol. 35, pp. 1031-1040, 2011. 


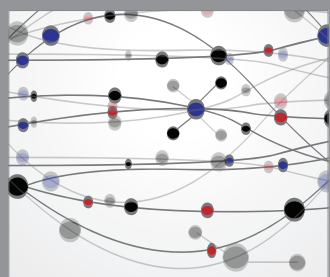

The Scientific World Journal
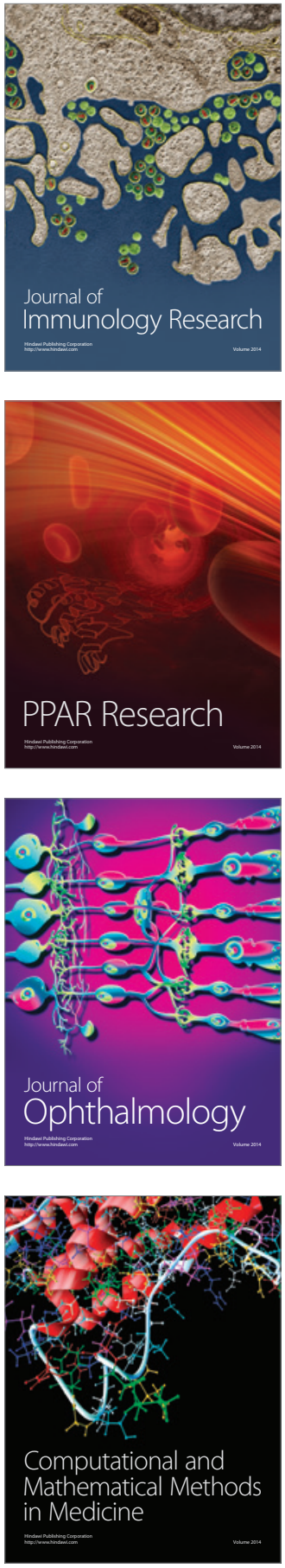

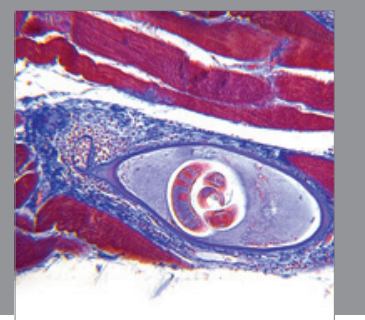

Gastroenterology

Research and Practice
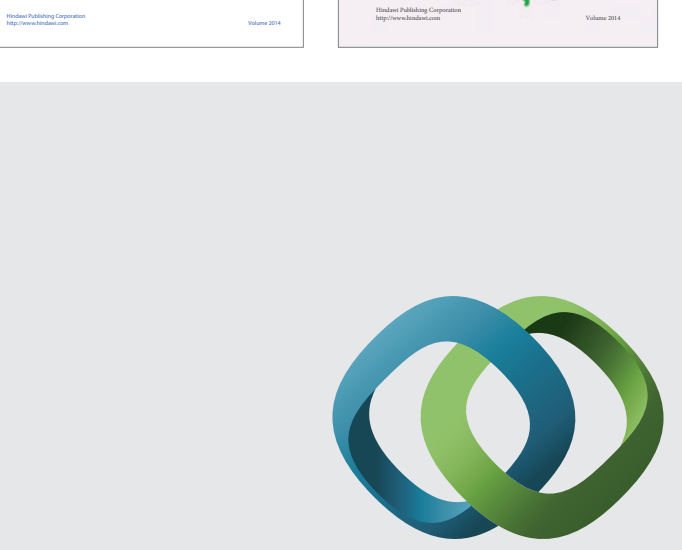

\section{Hindawi}

Submit your manuscripts at

http://www.hindawi.com
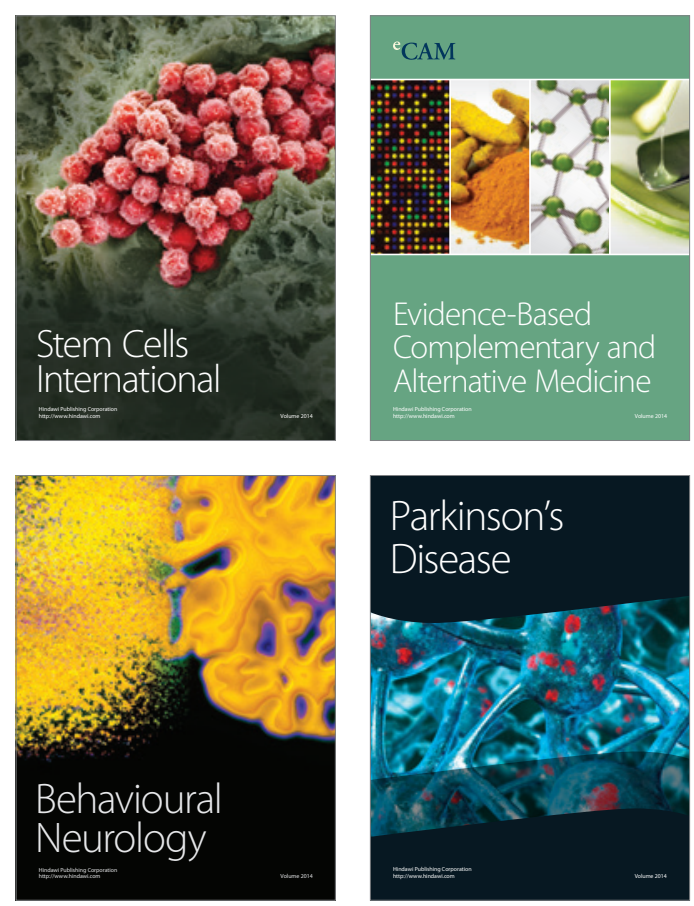

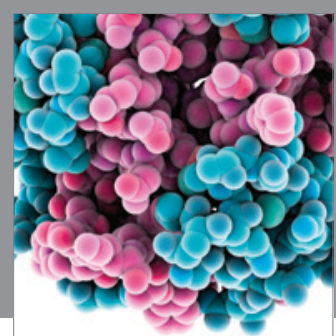

Journal of
Diabetes Research

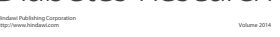

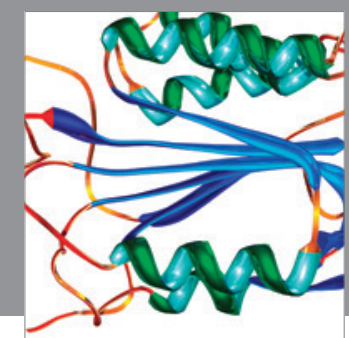

Disease Markers
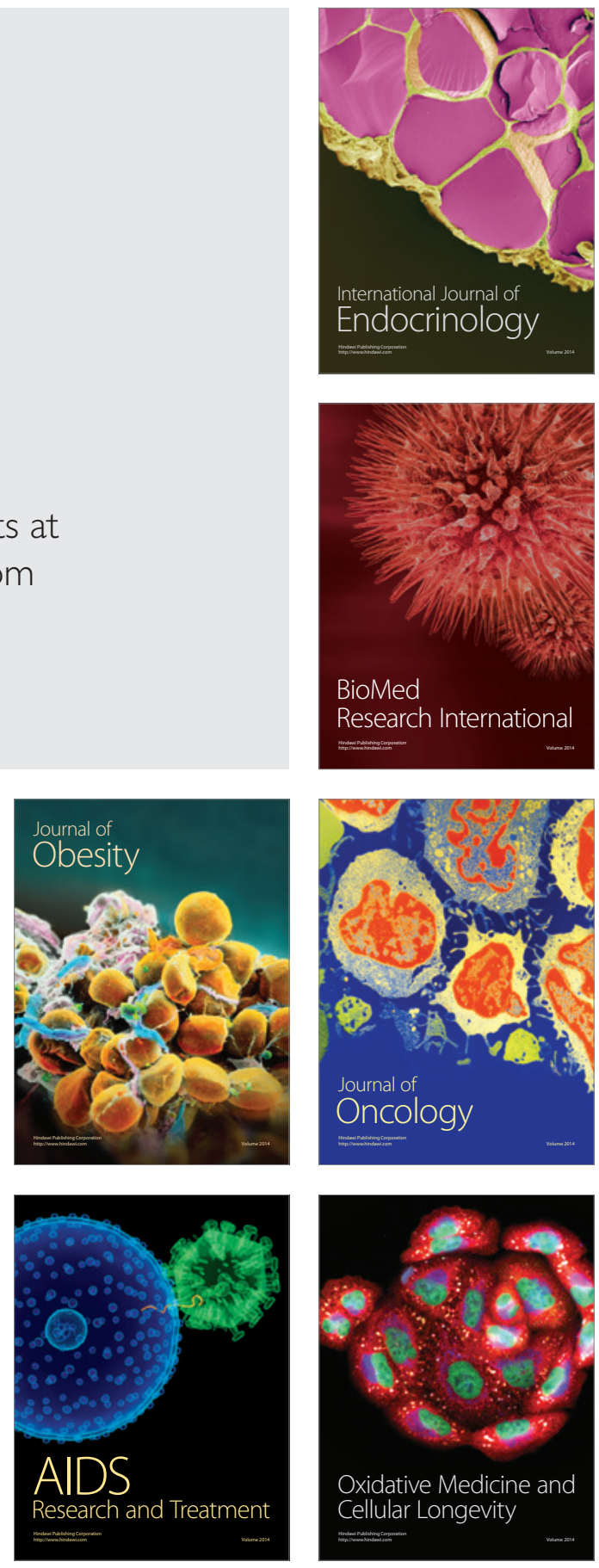